Journal of Applied Veterinary Sciences, 4(1): 1- 4 (April,2019).

ISSN: online; 2090-3308, print: 1687-4072

Journal homepage : https://javs.journals.ekb.eg

\title{
DETECTION LIMITS OF LIVE ATTENUATED POULTRY VIRAL VACCINE TESTING METHOD FOR DETECTION OF BACTERIAL CONTAMINATION
}

\author{
Hanan M. Ibrahim; Hanan A. Ahmed; Nourhan Nagy*; Gina M. Mohamed; Shafai, S.M. and \\ Aly, A.M. \\ Central Laboratory for Evaluation of Veterinary Biologics , Abbasia, Cairo, Egypt. \\ *Corresponding author: Nourhan Nagy; E-mail: nouranagy74@yahoo.com
}

\begin{abstract}
A total number of 27 vaccine vials including 3 batches of 3 different types of live attenuated poultry viral vaccines (tissue culture Gumboro vaccine, egg adapted colored ILT vaccine and egg adapted non colored ILT vaccine) were experimentally contaminated with 1,5,10 CFU of Salmonella typhimurium reference strain/dose then subjected for sterility testing as referenced in OIE. Further dilution was carried out of vaccines showing negative results. The results of statical analysis showed that there is a significant difference between direct inoculation of the vaccines and their dilutions. It could be concluded that the applied testing method is appropriate for testing sterility of living attenuated poultry viral vaccines but testing of some of such vaccines need further dilutions to obtain accurate results.
\end{abstract}

Keywords: Bacterial contamination, Detection limits, live attenuated vaccines, Salmonella.

\section{INTRODUCTION}

Poultry vaccines are widely applied to prevent and control contagious diseases. Their uses in poultry production are aimed at avoiding and minimizing clinical disease at farm level, thus increasing production (Marangon et al., 2005). Adequate assurance of sterility and freedom from contamination can only be achieved by proper control of the primary materials used and their subsequent processing and storage. Testing of the product is necessary to check that this control has been achieved (CFR, 2015 and OIE, 2016). Sterility testing is designed to demonstrate the presence or absence of extraneous viable contaminating microorganisms in biologics (Lee, 1990).

The definition used for "validation" in the ISO standard 8402 is "confirmation by examination and provision of objective evidence that the particular requirements for a specific intended use are fulfilled". This definition gives the impression of confined and well-defined (exact) operations. Test methods are normally developed for an intended application range. The reference to particular requirements must in many cases be interpreted in a flexible way as the requirements can be of general nature.
Original Article:

DOI: https://dx.doi.org/10.21608/javs.2019.62668

Received 10 February, 2019.

Accepted 23 March, 2019.

Published in April, 2019.

This is an open access article under the Attribution 4.0 (CC-BY) International License. To view a copy of this license, visit

http://creativecommons.org/licenses/by/4 $.0 /$

J. Appl. Vet. Sci., 4(1): 1- 4. term of the Creative Commons

In the validation process is an estimate made of the representativeness, repeatability and reproducibility of the test method (Annex -1, 2017) aiming to secure that the test methods are good enough to qualify the tested vaccines. How much effort should be spent on validation must be decided on a case by case basis. If large economic values as well as considerable health, safety and environmental issues are involved, much more emphasis must be paid to the validation of the test methods. The frequency of use of the test method should also be considered when determining the extent of validation. The total consequences of wrong results are of course larger for methods in extensive use than for test methods used occasionally (Excel kontrol, en 2008 and Excel kontrol version 2.1 (2008).

This study aims to assess the validity of used method for testing the sterility of live attenuated poultry viral vaccines.

\section{MATERIALS AND METHODS}

\section{Sample}

Twenty seven vaccine vials including 3 batches (3 vials of each batch) of live attenuated viral poultry vaccines including tissue culture Gumboro vaccine, egg adapted colored ILT vaccine and egg adapted non colored ILT vaccine were subjected to the present study. 


\section{Spike}

Salmonella typhimurium reference strain was kindly obtained from the Reference Strain Bank, Central Laboratory for Evaluation of Veterinary Biologics (CLEVB) Abassia, Cairo.

\section{Preparation of the inoculum}

Three beads of Salmonella typhimurium strain were enriched in 3 tubes of peptone water and incubated at $37^{\circ} \mathrm{C}$ overnight. These broth cultures were tenfold serially diluted to be used in spiking the tested vaccines at different 3 levels of contamination according to Reynolds (2005) as follow:

$1^{\text {st }}$ level reveals $1 \mathrm{CFU} /$ dose in vaccine vial.

$2^{\text {nd }}$ level reveals $5 \mathrm{CFU} /$ dose in vaccine vial.

$3^{\text {rd }}$ level reveals $10 \mathrm{CFU} /$ dose in vaccine vial.

\section{Testing method}

The used sterility testing method was carried out following up the directions of OIE (2016) where each vaccine vial was dissolved in $2 \mathrm{ml}$ sterile distilled water then inoculated to thioglycolate broth in a ratio 1:15, followed by experimentally contamination with a level of bacterial concentration then incubated at $35^{\circ} \mathrm{C}$ for 14 days and examined for bacterial growth turbidity .

Any suspected turbidity in the medium containing spiked vaccine was sub-cultured on tryptic soya agar medium for detection of the bacterial colonies growth. Due to presence of negative result, all spiked vaccines were further diluted to 5,10 and $20 \mathrm{ml}$ sterile distilled water then respiked with the same 3 levels of contamination and reexamined.

\section{Media and reagent performance}

According to ISO /11133-1 (2014), the used media in this study were tested before inoculation to validate their efficacy by measuring the productivity and selectivity.

\section{Criteria of validation}

The validation study depends on different parameters and tools to evaluate if the method is fit to use in check vaccine sterility or not. The parameters used were selectivity, trueness, sensitivity, specificity, concordance, repeatability and reproducibility according to the requirement of ISO 16140 (2017) tacking in consideration that:

Trueness $=(\mathrm{a}+\mathrm{d}) / \mathrm{n} * 100$

Sensitivity $=a /(a+b) * 100$

Specificity $=\mathrm{d} /(\mathrm{c}+\mathrm{d}) * 100$

Concordance-Index Kappa $=2(\mathrm{ad}-\mathrm{bc})\{(\mathrm{a}+\mathrm{c})(\mathrm{c}$ $+d)+(a+b)(b+d)\}$.

\section{Where:}

$a=$ Number of positive agreements.

$b=$ Number of false negatives.

$\mathrm{c}=$ Number of false positives.

$\mathrm{d}=$ Number of negative agreements.

$\mathrm{n}=$ Total number of results.

Table 1: Concordance-Index kappa according to ISO/TC 34/SC 9/WG3 N027

\begin{tabular}{|c|c|}
\hline Kappa value & Kappa index \\
\hline$<0.1$ & No \\
\hline $0.1-0.4$ & Low \\
\hline$>0.4-0.6$ & Distinct \\
\hline$>0.6-0.8$ & High \\
\hline$>0.8-1$ & Almost total \\
\hline
\end{tabular}

\section{RESULTS}

The obtained results showed that the contamination was able to be detected in all spiked batches of tissue culture vaccine at all levels of contamination (level1 "1 CFU/dose", level 2 "5 CFU/dose" and level 3 "10 CFU/dose") as demonstrated in table (2).

Table 2: Limits of Detection (LOD) for tissue culture Gumboro vaccine

\begin{tabular}{|c|c|c|c|}
\hline \multirow{2}{*}{$\begin{array}{c}\text { Levels of } \\
\text { contamination }\end{array}$} & Batch 1 & Batch 2 & Batch 3 \\
\cline { 2 - 4 } $\begin{array}{c}\text { Level 1 } \\
(1 \text { CFU/vaccine vial })\end{array}$ & $+\mathrm{ve}$ & $+\mathrm{ve}$ & $+\mathrm{ve}$ \\
\hline $\begin{array}{c}\text { Level 2 } \\
(5 \mathrm{CFU} / \text { vaccine vial })\end{array}$ & $+\mathrm{ve}$ & $+\mathrm{ve}$ & $+\mathrm{ve}$ \\
\hline $\begin{array}{c}\text { Level 3 } \\
(10 \text { CFU/vaccine } \\
\text { vial })\end{array}$ & $+\mathrm{ve}$ & $+\mathrm{ve}$ & $+\mathrm{ve}$ \\
\hline
\end{tabular}

Table (3) revealed that all spiked batches of egg adapted color vaccine showed detected contamination at 2 and 3 batches of vaccine vials in level 1 (1CFU/dose) while such contamination was detected with level 2 (5 CFU/dose) and level 3 (10 $\mathrm{CFU} /$ dose) in all tested batches.

Table 3.: Limits of Detection (LOD) for egg adapted colored ILT vaccine

\begin{tabular}{|c|c|c|c|}
\hline \multirow{2}{*}{$\begin{array}{c}\text { Levels of } \\
\text { contamination }\end{array}$} & \multicolumn{3}{|c|}{ Tested vaccine batches } \\
\cline { 2 - 4 } & $\begin{array}{c}\text { Batch } \\
\text { Batch }\end{array}$ & $\begin{array}{c}\text { Batch } \\
3\end{array}$ \\
\hline $\begin{array}{c}\text { Level 1 } \\
(1 \text { CFU/vaccine } \\
\text { vial) }\end{array}$ & $+\mathrm{ve}$ & $-\mathrm{ve}$ & $-\mathrm{ve}$ \\
\hline $\begin{array}{c}\text { Level } 2 \\
(5 \mathrm{CFU} / \mathrm{vaccine} \\
\text { vial })\end{array}$ & $+\mathrm{ve}$ & $+\mathrm{ve}$ & $+\mathrm{ve}$ \\
\hline $\begin{array}{c}\text { Level } 3 \\
(10 \mathrm{CFU} / \mathrm{vaccine} \\
\text { vial })\end{array}$ & $+\mathrm{ve}$ & $+\mathrm{ve}$ & $+\mathrm{ve}$ \\
\hline
\end{tabular}


Hanan M. Ibrahim, et al.

On the other side, the results tabulated in table (4) revealed that in all spiked batches of egg adapted non colored vaccine, the contamination could not be detected at 2 out of 3 batches of vaccine vials with level 1 (1 CFU/dose) while it could be detected at level 2 (5 CFU/dose) and level 3 (10 $\mathrm{CFU} /$ dose) in all batches.

Table 4: Limits of Detection (LOD) for egg adapted non colored ILT vaccine

\begin{tabular}{|c|c|c|c|}
\hline \multirow{2}{*}{$\begin{array}{c}\text { Levels of } \\
\text { contamination }\end{array}$} & \multicolumn{3}{|c|}{ Tested vaccine batches } \\
\cline { 2 - 4 } & Batch 1 & Batch2 & Batch3 \\
\hline $\begin{array}{c}\text { Level 1 } \\
(1 \mathrm{CFU} / \text { vaccine vial })\end{array}$ & $+\mathrm{ve}$ & -ve & -ve \\
\hline $\begin{array}{c}\text { Level 2 } \\
(5 \mathrm{CFU} / \text { vaccine vial })\end{array}$ & $+\mathrm{ve}$ & $+\mathrm{ve}$ & $+\mathrm{ve}$ \\
\hline $\begin{array}{c}\text { Level 3 } \\
(10 \mathrm{CFU} / \mathrm{vaccine} \\
\text { vial })\end{array}$ & $+\mathrm{ve}$ & $+\mathrm{ve}$ & $+\mathrm{ve}$ \\
\hline
\end{tabular}

The obtained results revealed that the tissue culture living attenuated viral vaccine (Gumboro); the specificity, sensitivity, trueness and concordance where 100,100, 100 and 1 consequently reflecting the validity of the used method in this vaccine type, while in colored and non colored egg adapted living attenuated viral ILT vaccines at level 1 contamination the specificity; sensitivity, trueness and concordance were 100, 50, 66.7 and 0.4 consequently as shown in table (5). These results were considered of low validity for the used method in these types of vaccines.

Table 5: Criteria of validation study for tested vaccines at level 1 of contamination (1 CFU/dose)

\begin{tabular}{|c|c|c|c|c|c|}
\hline \multirow[b]{2}{*}{$\begin{array}{c}\text { Tested } \\
\text { vaccine }\end{array}$} & \multicolumn{5}{|c|}{ Criteria of validation } \\
\hline & 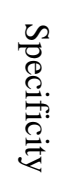 & 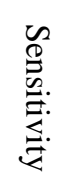 & $\begin{array}{l}\exists \\
\vec{\Xi} \\
\stackrel{0}{0} \\
\infty \\
\infty\end{array}$ & 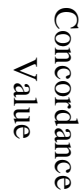 & 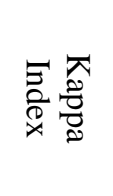 \\
\hline $\begin{array}{l}\text { Tissue } \\
\text { culture } \\
\text { living viral } \\
\text { vaccine }\end{array}$ & 100 & 100 & 100 & 1 & $\begin{array}{c}\text { Almost } \\
\text { total }\end{array}$ \\
\hline $\begin{array}{l}\text { Egg adapted } \\
\text { colored } \\
\text { living viral } \\
\text { vaccine }\end{array}$ & 100 & 50 & 66.7 & 0.4 & Low \\
\hline $\begin{array}{l}\text { Egg adapted } \\
\text { non colored } \\
\text { living viral } \\
\text { vaccine }\end{array}$ & 100 & 50 & 66.7 & 0.4 & Low \\
\hline
\end{tabular}

Further dilution of tested vaccine at level 1 contamination indicated that the egg adapted colored and egg adapted non colored ILT vaccines the contamination could not be detected at first dilution (5ml) while could be detected in the other 2 dilutions, but in the tissue culture living attenuated viral vaccine, the contamination was detected in first, second and third dilution $(5 \mathrm{ml}, 10 \mathrm{ml}, 20 \mathrm{ml})$ as tabulated in table (6).

Table 6: Limits of Detection (LOD) for diluted tested vaccines

\begin{tabular}{|l|c|c|c|}
\hline \multirow{2}{*}{ Tested vaccine } & \multicolumn{3}{c|}{$\begin{array}{c}\text { Detection of } \\
\text { contamination with } \\
\text { vaccine dilutions }\end{array}$} \\
\cline { 2 - 4 } & $5 \mathrm{ml}$ & $10 \mathrm{ml}$ & $20 \mathrm{ml}$ \\
\hline $\begin{array}{l}\text { Egg adapted colored } \\
\text { vaccines }\end{array}$ & $\mathbf{- v e}$ & $\mathbf{+ v e}$ & $\mathbf{+ v e}$ \\
\hline $\begin{array}{l}\text { Egg adapted non colored } \\
\text { vaccines }\end{array}$ & $\mathbf{- v e}$ & $\mathbf{+ v e}$ & $\mathbf{+ v e}$ \\
\hline $\begin{array}{l}\text { Tissue culture living } \\
\text { attenuated viral vaccines }\end{array}$ & $\mathbf{+ v e}$ & $\mathbf{+ v e}$ & $\mathbf{+ v e}$ \\
\hline
\end{tabular}

The obtained results of tested vaccines after dilution clarified that in case of tissue culture living viral vaccine; the specificity, sensitivity, trueness and concordance were 100,100,100 and 1 consequently while in case of egg adapted colored and non colored living attenuated ILaT vaccines the specificity, sensitivity, trueness and concordance where $100,83.3,88.9$ and 0.88 consequently as tabulated in table (7).

Table 7: Criteria of validation study for all contamination levels in examined living attenuated viral vaccines after dilution

\begin{tabular}{|c|c|c|c|c|c|}
\hline \multirow[b]{2}{*}{ Tested vaccine } & \multicolumn{5}{|c|}{ Criteria of validation } \\
\hline & 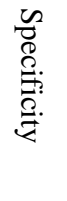 & 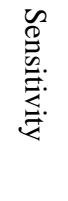 & $\begin{array}{l}\exists \\
\stackrel{\Xi}{D} \\
\stackrel{D}{D} \\
\infty \\
\infty\end{array}$ & 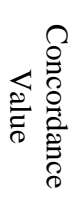 & 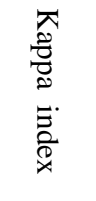 \\
\hline $\begin{array}{l}\text { Tissue culture living } \\
\text { viral vaccine }\end{array}$ & 100 & 100 & 100 & 1 & $\begin{array}{c}\text { Almos } \\
\text { t total }\end{array}$ \\
\hline $\begin{array}{l}\text { Egg adapted colored } \\
\text { living viral vaccine }\end{array}$ & 100 & 83.3 & 88.9 & 0.88 & $\begin{array}{l}\text { Almos } \\
\text { t total }\end{array}$ \\
\hline $\begin{array}{l}\text { Egg adapted non } \\
\text { colored living viral } \\
\text { vaccine }\end{array}$ & 100 & 83.3 & 88.9 & 0.88 & $\begin{array}{c}\text { Almos } \\
\text { t total }\end{array}$ \\
\hline
\end{tabular}

\section{DISCUSSION}

It was stated that sterility testing is a process that confirm the presence or absence of extraneous viable contaminating microorganisms in biologics (Lee, 1990). All obtained results through the present 
study indicate that the used method for detection of bacterial contamination of poultry viral vaccines; either tissue culture or egg adapted; is fit to fulfill such purpose. It is well known that adequate assurance of sterility and freedom from contamination is necessary to check vaccine validity (CFR, 2015 and OIE, 2016).

Kappa index in different contamination levels in all tested vaccines after dilution was ranged between high Kappa index and almost total, so it can be concluded that the test method applied for check the sterility of living attenuated poultry viral vaccines is fit for tissue culture vaccine and egg adapted colored or non colored vaccines after dilution which was carried out to overcome the inhibitor substance (antibacterial) which affects the first level of contamination (1CFU/dose) and accordingly further dilution of examined vaccines is recommended when negative results obtained to minimize the effect of these substances.

\section{CONCLUSION}

These findings secure that the used test method is good enough to qualify the tested vaccines.

\section{Declaration of Competing interest}

On behalf of all authors, I hereby declare that no conflict of interest may interfere with the publication of the manuscript.

\section{REFERENCES}

ANNEX 1. 2017. Manufacture of sterile Medical Prroducts, European Commission December 2017.

CODE OF FEDERAL REGULATION "CFR". 2015. Title 9. Animals and Animal Products.

EXCEL KONTROL (EN) 2008. NEW CONTROL XCHART FOR A NEW CONTROL CHART (Excelcontrol@gmail.com).

EXCEL KONTROL VERSION 2.1. 2008. Rules for out of control

ISO8402. 1994. Quality management and quality assurance - vocabulary Rev. Sci. Tec. Off. Epiz., 20

ISO/TS 11133-1. 2014. General guideline on quality assurance for preparation of culture media in the laboratory.

ISO TS 34SC9W03 / 16140. 2017. Microbiology of the food chain - method validation- part 3 protocol for the verification of reference and validated alternative methods implemented in single laboratory Published by the Office of the Federal Register. National Archives and Records Administration

OIE 2016. Infection disease in OIE quality standard and guidelines for veterinary laboratories (world organization for health).
LEE, J.Y. 1990. Investigating Sterility Test Failure. Pharm. Technol., 38-43.

MARANGON S. AND BUSANI L. 2005. The use of vaccination in poultry production. Rev. Sci. Tec. Off. Epiz., 20 Reynolds, J.: American Society for Microbiology, 6, 26 (1), 265-274.

REYNOLDS,J. 2005. American Society for Microbiology, 6, 26 (1), 265-274.

ROSS TECH NOTE 2008. Drinking Water Vaccination- a few simple roles. Africa Ferndandez, Company Veterinarian, Avigen, September 2008.

How to cite this article:

Hanan M. Ibrahim; Hanan A. Ahmed; Nourhan Nagy; Gina M. Mohamed; Shafai, S.M. and Aly, A.M. 2019. Detection Limits of Live Attenuated Poultry Viral Vaccine Testing Method for Detection of Bacterial Contamination. Journal of Applied Veterinary Sciences, 4(1): 1- 4.

DOI: https://dx.doi.org/10.21608/javs.2019.62668 